\title{
Job satisfaction and social rewards in the social services
}

Jorunn Theresia Jessen, Researcher, Norwegian Social Research (NOVA), Norway.

E-mail: Jorunn.Jessen@nova.no 


\begin{abstract}
This article investigates the sources of job satisfaction among practitioners and managers employed in the Norwegian public social services and the professionals' perception of social rewards in particular. Being valued, receiving praise and positive feedback are considered to be important aspects of job satisfaction. Nevertheless the expertise and competence of social workers is not always acknowledged. A central question raised is whether the workers' job satisfaction is influenced by their opportunities for support and recognition, compared to other (intrinsic and organisational) rewarding aspects available to social service workers. The empirical data come from a 2004 quantitative survey among social workers in local welfare agencies. Despite conflicting demands and lack of resources in the front line services, findings indicate that managers and practitioners perceive their work as overall equally satisfying. Still, the managers find their job more interesting and challenging due to their position, reporting higher feelings of accomplishment and control over work. Receiving public approval and co-worker support are positively associated with job satisfaction within both work positions, while superior support and client recognition were found to be significantly rewarding aspects to the practitioners only. The final discussion addresses the challenges for an organizational climate that sustain the worth and contribution of social professionals
\end{abstract}

Keywords: job satisfaction, social service workers, rewards, social support and recognition.

\title{
Introduction
}

Job satisfaction is central to the work lives of employees and to the effective use of personnel within organisations (Foster 2000, Koeske et al 1994). When satisfied at work, employees are likely to be more stable, productive and accomplished towards organisational goals. According to research, human service workers who derive satisfaction from their work are more committed and provide better services to their clients, than those who are dissatisfied (Acker 1999). On the contrary, literature conclude that dissatisfaction and negative interactions between individuals and their environments may contribute to lower job performance, more turnover or intention to quit (Koeske and Koeske 2000). As with the public welfare services in most countries, the social services in Norway have been associated with high demands in terms of time pressure, role ambiguity and work overload (Stjernøy 1985, Solheim og Øvrelid 2001). The responsibilities of social workers are potentially stressful, implying conflicting demands and complexity in tasks (Halvorsen 2005). Since social service work often are associated with large caseloads, stress and resources too limited to perform the jobs satisfactorily, the issues of motivation and job satisfaction are important to consider.

The purpose of this paper is to investigate the sources of job satisfaction among social workers in the public social services in Norway and to explore how various rewarding aspects contribute to the workers' overall level of satisfaction. Particular emphasis is put on extrinsic and social rewards, examining whether the workers' job satisfaction is influenced by their opportunities for acknowledgement, compared to other intrinsic and organisational aspects available in the workplace. This has particular relevance for social workers, whose jobs often combine a high proportion of user contact with personal and emotional involvement

Most often, the research literature approaches the question of job satisfaction by studying professionals in general, and seldom differentiates between work positions. The few studies comparing job satisfaction by hierarchal positions in the social work field, show that the social work staff expresses more dissatisfaction across a wide range of issues than the managers do (Balloch et al. 1998). Because of the hierarchical differences between 
practitioners and managers concerning responsibilities and available rewards deriving from social work practice, this paper differentiate between the two positions to avoid potential bias and thus misinterpretations by just examining the social work staff in general. Since leaders in social service agencies often are holding both managerial and supervising positions, they more often have the authority to make reviewed decisions. Due to the various challenges and demands encountered in the two positions, we expect social service managers and practitioners to perceive their work situation and rewards differently. Job satisfaction arises from the ability to act in accordance with ones motivation, having a need or want satisfied. In this sense, there is a close link between motivation and job satisfaction (Herzberg 1959) ${ }^{1}$. The workers' motivation and job satisfaction may be influenced and improved by rewards coming from the organisation, the nature of the work itself or through their interaction with citizens and clients. Furthermore, being valued, receiving praise and positive feedback will maintain and reinforce intrinsic motivation, if this is perceived as supporting the workers' self-esteem (Kalleberg 1977). The most unsatisfactory aspects of the social workers' job context arise from not being valued by their employers and wider society (Huxley et al 2005). Similarly, a good reputation is considered to have a positive impact on professional pride and motivation as a central part of the professional's rewards (Evetts 2006). Yet, previous research studies focusing on job satisfaction and social workers have given only limited attention to social rewards and external acknowledgement.

In Norway, social services are administered by a professionally trained core staff of social workers, having the authority of local administrators for both financial assistance and assistance in kind, i.e. services including help in crisis, family counselling, drug abuse and child welfare. The financing and administration of social services are the responsibilities of the local municipalities. The use of discretionary power and means testing is crucial in cases of social assistance in the Norwegian social services. Social assistance benefits are based on selective principles and means assessed by the front line workers through individual assessment of income and assets. The system of social assistance is a final social safety net for individuals, ensuring adequate resources and helping them become self-supporting, and is only disbursed when the clients have utilized their possibility to obtain income from work or other social insurance benefits². (Lødemel 2001).

Despite a continuing struggle for professional status, the expertise and competence of social professionals are not always acknowledged. Emerging evidence from the front line of social services indicate that the practice environment suffers from the lack of public support for professional social work, (Healy and Meagher 2004). Social workers are characterized as subject to systems of managerial control that in many countries indicate changes in workplace conditions, enabling less opportunities for professional development and recognition (Harris and McDonald 2000, Healy and Meagher 2004). Based on these assumptions, we expect external appreciation as well as social support to be significant sources of motivation to social service workers, influencing their job satisfaction. In the following sections I review the relevant literature and conceptual issue of job satisfaction for comparative purposes, before presenting and discussing the empirical results.

\section{Literature review}

In sociological literature, job satisfaction is defined as an overall affective orientation on the part of individuals toward work roles which they are presently occupying (Kalleberg 1977). Overall satisfaction is directed towards the individuals' total job situation and differs from satisfaction with the more specific dimensions or aspects of his/her work role. Accordingly, job satisfaction implies a subjective and emotional reaction toward different aspects of the job, perceived as an emotional state resulting from the appraisal of ones situation, 
linked with the characteristics and demands of ones work (Spector 1997, Arches 1991). Since job satisfaction arises from the ability to act in accordance with ones motivation, the relationship between what individuals wants from their work and what they actually gain are considered important (Abu-Bader 2000). The question of satisfaction from work cannot be considered without taking into account the values that people attach to their work activity (Kalleberg 1977). The satisfaction an employee obtains from work is a function of his/ her individual motives and values, and not only of the objective properties of that job. The values constitute potential sources of job rewards such as enjoyment of the tasks themselves or gratification received from helping people, reflecting the workers desire to be stimulated and challenged by the job and to exercise acquired skills at work.

According to the general job satisfaction literature many of the relevant aspects (or facets) of the job can be organized into a limited number of critical dimensions, and are often differentiated between intrinsic and extrinsic motivational rewards (Herzberg, 1959). Based on this analytical distinction, Koeske et al. (1994) has developed a three factor structure (job satisfaction scale) that reflects the intrinsic qualities of the work role, the organisational aspects and the more extrinsic ones.

The intrinsic rewards refer to the inherent features of work and characteristics associated with the task itself, for instance the capacity to confer to workers a sense of achievement, interest, responsibility or accomplishment (Kalleberg 1977). Valuation of this dimension thus reflects the workers' desire to be stimulated and challenged by the job and to be able to exercise acquired skills at work. According to previous research, intrinsic rewards have important implications for social workers' overall satisfaction at work and desire to commit to their job (Balloch et al. 1998, Penna et al.1995, Huxley et al.2005, Papadaki 2006). Also studies of child welfare workers indicate that a sense of mission or strong commitment ${ }^{3}$ to working in child welfare is an important factor in job satisfaction as well as client outcome (Stalker 2007). Despite stressful working conditions most of them felt committed to making a contribution to improve the lives of children, according to the professional code of ethics and ideal of care and service that regulate their relations with clients.

Thus, the rewards coming from the intrinsic aspects of work often serve as the most important motivational factors for social workers who interact with clients, by providing help and assistance, hoping to achieve change and improvement in clients' lives. In addition to the altruistic motives, studies have demonstrated the importance of self-directed motives related to personal interests and quest for working tasks that individuals find meaningful and engaging (Jensen 2003)4.

The extrinsic rewards often refer to job characteristics that are external to the tasks themselves, providing benefits or rewards like pay, job security and recourse adequacy (Herzberg 1959, Kalleberg 1977). The extrinsic dimension also include the more symbolic rewards in terms of client recognition and public approval and the social support in relationship with co-workers and whether the job permits chances for the workers to take personal interests in each other as colleges. Valuation of this dimension reflects a workers desire for the satisfaction of social needs from the work activity.

First, being valued, receiving praise and support and positive feedback are considered to be a central part of the professionals' rewards and identities (Gibbs 2001). The most unsatisfactory aspects of the social workers job context arise from not being valued by their employers and wider society, and some of the most satisfactory from the support of colleagues and supervisors (Huxley et al. 2005). In literature however, theorists disagree upon this issue. According to Le Grande (2003) the degree of approval from the outside world seems of little or no importance as a motivational reward, compared to other personal 
gratifications deriving from altruistic actions. He claim that gratification deriving from altruistic actions primarily depends on the sort of help that professionals can offer, on the extent to which they have the opportunities to help, and on the benefits to the users concerned. On the contrary, Evetts (2006) argues that a good reputation has a great impact on professional pride and motivation as a central part of the professional's rewards.

Second, being valued at the work place, receiving support and assistance from leaders, supervisors or employers, is considered to be helpful when coping with stress (Thompson et al. 1994). Studies have shown that stress and satisfaction are closely interrelated (McLean and Andrew 2000). Receiving support has a positive impact on overall satisfaction and mental health, mediating the negative effects of demands, stress and exhaustion (McLean 1999, Huxley 2005).

Social Support is sought for several reasons (Carver et al 1989). One is seeking support for instrumental reasons, such as the more practical advice, assistance or information, named problem focused coping. Another is seeking support for emotional reasons; getting moral support, sympathy or understanding, named emotion-focused coping. According to Himle et al.(1989), emotional support given at the work place is positively associated with job satisfaction To talk about stress-related feelings may help people to better cope and find resolutions to their problems when supportive social networks are available at work. However, researches on social support show somewhat different conclusions related to the various supporting sources offered by co-workers and managers. While some studies suggest that colleagues are a primary source of support to social workers (Gibson et al 1989, Jones et al 1991), others tell us that support from managers and supervisors are less important in relieving stress (Regehr et al. 2004).

The organisational dimension represents a valuation of job aspects external to the task itself, and is viewed in contrast conceptually to the intrinsic dimension (Kalleberg 1977). This dimension refers to various aspects of the workers' job context, such as workload, resources, control and time pressure. The organisational rewards may include good working conditions, freedom from conflicting demands and from excessive amounts of work, pleasant physical surroundings and enough resources and time to do the work. Since the organisational resources available to the employees will depend on power and managerial position, the workers also have different opportunities to attain and control the job rewards provided.

In Norway, a previous study of social service workers conducted by Stjernø (1985), suggested that structural aspects of work in terms of job demands have a negative effect on job satisfaction when combined with the lack of professional control over the work situation ${ }^{5}$. In addition, dissatisfaction may stem from other organisational and structural aspects of work; like the way the department is managed and organisational crisis or restructuring (Blood 1969). Since the nature of social work itself is potentially stressful, several organisational aspects have been identified as important predictors of job dissatisfaction (Collins 2008, Koeske and Kelly 1995). Especially among newly qualified workers, the workload and resource limitations combined with the lack of support and supervision, are factors causing frustrations (March and Triseliotis 1996).

According to literature, dissatisfied workers may develop withdrawal intentions and their contribution to the organisation will often be minor (Freund 2005). On the other hand, social professionals who derive satisfaction from their occupation are likely to be more committed and provide higher quality services to their clients, than those who are dissatisfied (Acker 1999). Satisfied workers are characterized as employees who feel that they have sufficient opportunities for professional development, proper guidance and a proper reward system (Bussing 1999). They also tend to stay in the organisation, contribute and invest their skills 
to achieve the organisational goals. To uncover the sources of satisfaction and explore the way employees estimate their work is therefore important for understanding the dynamic and structure of working in the welfare services.

\section{Data}

The empirical data set in this paper comes from a quantitative survey among social workers, employed in the Norwegian public social services in 2004. The aim of this study was to examine the variation in autonomy, discretion and skilled competence among workers within the National Insurance and Social Services. The research was conducted through a random sample of all the municipalities in Norway, and based on a postal questionnaire survey. The questionnaire, consisting of eighty-five items in all, was mailed to practitioners and local managers of the two agencies in each selected municipality. The respondents studied in this current paper are restricted to social workers only, selected from the random sample comprising 25 per cent of all the local social service agencies. From the final sample of 647 respondents, we received answers from 445 social service workers. This relatively high response rate of 70 per cent indicates interest. The average age of the respondents was 43 year and the majority of the workers were females, comprising 78 per cent. Their work experience varied from zero to 34 years, with a mean score of 6 years. The majority (83 per cent) of the work staff handled cases and applications for benefits, whereas 64 per cent were responsible for continuous observation (follow up) and guidance of clients. While 78 per cent of the respondents $(n=335)$ were working in non-managerial positions as front line practitioners, the managers ${ }^{6}$ holding both senior and middle level positions comprised 22 per cent $(n=100)$. Managers are more or less involved in administration, planning, employment and supervision of employees and generally have less contact with service users, compared to the practitioners. The majority of managers are women (75 per cent).

\section{Measures and study variables}

In this paper a sample set of twenty one items are analysed, aimed at measuring the extent to which the workers experience motivational rewards in terms of different intrinsic, organisational and social job aspects ${ }^{7}$. Within these three dimensions five scales of job rewards were utilized (described below). The internal reliability of these scales was calculated using Cronbach alpha in order to assess the reliability among these scales. The score for each sample, related to each index is given where appropriate in the tables.

Following the analytical distinction of Kalleberg (1977) and Koeske et al. (1994), the scales constructed for the intrinsic dimension refer to the workers' opportunities and desire to be rewarded and challenged by the job (personal rewards) and their feeling of accomplishment. The personal rewards is a five- item scale, which measures how interesting and varying the job is perceived to be, allowing the worker to be helpful and to develop his/hers abilities for acquiring new skills. The feeling of accomplishment is a two- item scale, measuring the workers' feeling of success in terms of work task quality and problem solving.

The organisational dimension of job satisfaction refers to the workers perceptions of job demands, clarity of goals and control (autonomy) offered by the work place. The items used to construct scales for the organisational dimensions are partly based on Karasek's (1979) Demand-Control model and partly based on the General Nordic Questioner (2001). Autonomy ${ }^{8}$ is a four-item scale, measuring the employees' scope of freedom to decide how to do their work, to work independently, to make decisions on their own and having the opportunities of discretionary decision-making. Job demands is a four- item scale, measuring the workers' perceptions of his/hers time pressure and work tempo, conflicting demands and inadequate resources to fulfil the work tasks. Clarity of goals is a two- item scale, measuring 
the extent of clearly defined goals and the job expectations directed towards the workers. In this study, the social reward dimension refers to various aspects of the social environment and the employees' work relations, measuring the degree of external public acknowledgement and internal social support, as perceived by the workers. Social support is based on the two following items: the opportunity to receive support from co-workers and support from superiors (managers), if needed. Extrinsic acknowledgment dimension is based on two single items measuring client recognition and public approval separately. The items used in this paper to measure the social rewards, are partly based on the General Nordic Questioner (ibid) and partly on the job-satisfaction scale of Koeske et al (1994). The items measuring social support in the work place are also in accordance with the later version of Kasarek's model (Kasarek and Theorell 1990).

The seven reward dimensions constitute potential sources of satisfaction to the workers. To empirically examine whether these rewards are interrelated or associated with the workers overall job satisfaction, statistical tests (one-way ANOVA) for mean differences between the two managerial work positions and tests for correlation (Pearson $r$ ) was conducted. The correlation analysis will no be able to identify the direction of causality of the interrelations, just the degree the units with high/low values of a variable tend to have high/low values of another variable. Examination of the effects and causality of this complexity by any sort of regression method is beyond the scope of this study. Since the direction of association between job satisfaction and different job rewards is not equivocal, but can go in both directions, the correlation analysis seems the most appropriate approach.

\section{Results}

Job satisfaction can be examined either in terms of the workers' general experience (overall job satisfaction) or as various reactions to different aspects of their job (job content, working conditions and interactions). The present study indicates a high level of overall satisfaction among the social service staff in general: in total $86 \%$ confirm being positively satisfied, $61 \%$ moderately and $24 \%$ very satisfied. Conversely, $14 \%$ did not express any positive satisfaction (being either very/moderately dissatisfied or neither dissatisfied nor satisfied). The findings show no statistically significant differences between managers and practitioners regarding their overall satisfaction. The level of overall job satisfaction reported is in line with the studies among statutory social workers in Great Britain (Collins 2008), and with a Norwegian survey conducted in 2007 suggesting a correspondingly level among public civil servants (Stat og Styring) ${ }^{9}$.

Being overall satisfied refers to a general affective orientation on the part of individuals toward their work roles and situation (Kalleberg 1977). Although the employees seem satisfied with their total job situation, they may still be dissatisfied with various aspects of their work, related to their working conditions, job content and tasks. In order to examine the employees' reactions to these different dimensions of work, the present study focus on the workers' perceptions regarding the different opportunities and rewards available at the social services. Table 1 presents the mean scores for some major intrinsic aspects by employment position, measuring the respondents perceptions of personal rewards (i.e. whether the job is perceived as interesting, allowing the workers to help others, to provide adjusted support to their clients, and to develop and use his/her abilities), and their feelings of accomplishment. The rewards examined are regarded as potential sources of satisfaction to the worker, and do not represent objective properties of his/hers work situation. 
Table 1. Intrinsic rewards. Mean and standard deviation scores $(n=448-453)$

\begin{tabular}{|l|r|r|r|r|r|}
\hline & \multicolumn{3}{|c|}{ Practitioners } & \multicolumn{2}{c|}{ Managers } \\
\hline & range & mean & Sd & mean & Sd \\
\hline Intrinsic rewards & & & & & \\
\hline Personal rewards & $(.72)$ & & & & \\
\hline Interesting work tasks** & $(1-5)$ & $\mathbf{4 . 0 5}$ & .76 & $\mathbf{4 . 3 3}$ & .65 \\
\hline Helping people & $(1-5)$ & $\mathbf{4 . 1 5}$ & .74 & $\mathbf{4 . 1 9}$ & .68 \\
\hline Providing adjusted support** & $(1-5)$ & $\mathbf{3 . 5 0}$ & .81 & $\mathbf{3 . 6 8}$ & .68 \\
\hline Self-development** & $(1-4)$ & $\mathbf{2 . 9 3}$ & .66 & $\mathbf{3 . 1 5}$ & .59 \\
\hline Task variation** & $(1-4)$ & $\mathbf{3 . 2 7}$ & .57 & $\mathbf{3 . 5 1 . 5 0}$ & \\
\hline & & & & & \\
\hline Feelings of accomplishment (.66) & & & & & \\
\hline Quality of work & $(1-5)$ & $\mathbf{3 . 9 0}$ & .53 & $\mathbf{3 . 9 3}$ & .53 \\
\hline Ability of problem solving** & $(1-5)$ & $\mathbf{3 . 9 9}$ & .53 & $\mathbf{4 . 1 6}$ & .46 \\
\hline
\end{tabular}

The responses vary the scales from 1- 5, ranging from "not at all" to "a very high degree", and from $1-4$, ranging from "totally disagree" to "totally agree". ANOVA * $p<0.05,{ }^{* *} p<0.01$

Being useful in terms of helping others and the challenges offered by varied and interesting work tasks are the highest ranked aspects among the intrinsic rewards, to practitioners as well as to managers. Still, the findings indicate that managers perceive and value their work even more interesting and varied than the subordinated workers do. Compared to the front line staff, managers perceive more opportunities to provide adjusted support to clients and more abilities to solve the problem. Managers holding senior and middle level positions also experience more opportunities to acquire skills and personal development.

Table 2 presents the mean ratings of various social rewards (extrinsic and organisational), showing the differences in responses between the managerial and the non- managerial positions within the social services.

Table 2. Social rewards. Mean and standard deviation scores $(n=449-454)$

\begin{tabular}{|l|r|r|r|r|r|}
\hline & \multicolumn{4}{|r|}{ Practitioners } & \\
\hline & range & mean & Sd & mean & Sd \\
\hline Social rewards & & & & & \\
\hline External acknowledgment: & & & & & \\
\hline Recognition from clients & $1-5$ & $\mathbf{3 . 0 7}$ & .82 & $\mathbf{3 . 0 8}$ & .76 \\
\hline Social approval from society & $1-5$ & $\mathbf{2 . 4 3}$ & .89 & $\mathbf{2 . 4 4}$ & .86 \\
\hline & & & & & \\
\hline Social support: & & & & & \\
\hline Support from co-worker* & $1-5$ & $\mathbf{4 . 3 6}$ & .76 & $\mathbf{4 . 1 3}$ & .87 \\
\hline Support from superiors & $1-5$ & $\mathbf{4 . 0 8}$ & .94 & $\mathbf{3 . 9 2}$ & .95 \\
\hline
\end{tabular}

The items 3 and 4 are scaled from 1- 5; ranging from "never/very seldom" to "very often/ always". The items 1 and 2 are scaled from 1-5, ranging from "not at all" to "very high degree". ANOVA * $p<0.05$

When examining the workers experiences of social rewards, findings show that the social work staff receive less external acknowledgement than expected. Both practitioners and managers experience an equally low degree of external rewards in terms of client recognition and public approval. The mean levels of social approval are rated 2.43 and 2.44 (equivalent to "very low/some degree"), while the mean levels of client recognition is rated 3.07 and 
3.08 (equivalent to "some degree") in each position. On the other hand, findings indicate that both groups experience good opportunities to receive social support from their colleges, while the opportunities of superior support seem somewhat less available to managers in particular ( 3.92). Nevertheless, the availability of co-worker support is the highest ranked aspect among social rewards.

The next table (3) presents the mean ratings of three main organisational aspects (control, demands and goals) by employment position. The organisational dimension is particularly relevant to human service organisations, and related to the workers job condition and type of tasks.

Table 3. Organisational rewards. Mean and standard deviation scores $(n=449-454)$

\begin{tabular}{|l|r|r|r|r|r|}
\hline & \multicolumn{3}{|c|}{ Practitioners } & \multicolumn{2}{c|}{ Managers } \\
\hline & range & mean & Sd & mean & Sd \\
\hline Organisational aspects & & & & & \\
\hline Job-demands (.72) & & & & & \\
\hline Rapid work tempo & $1-4$ & $\mathbf{3 . 1 1}$ & .62 & $\mathbf{3 . 2 3}$ & .58 \\
\hline Not enough time to do & & & & & \\
\hline my work properly (reversed) & $1-4$ & $\mathbf{2 . 8 0}$ & .74 & $\mathbf{2 . 9 0}$ & .74 \\
\hline Conflicting demands* & $1-4$ & $\mathbf{2 . 8 4}$ & .74 & $\mathbf{3 . 0 4}$ & .64 \\
\hline Lack of ressources to & & & & & \\
\hline solve my tasks* & $1-5$ & $\mathbf{3 . 0 4}$ & .86 & $\mathbf{3 . 3 8}$ & .84 \\
\hline & & & & & \\
\hline Autonomy (.70) & & & & & \\
\hline Freedom to decide how & & & & & \\
\hline to perform my work** & $1-4$ & $\mathbf{3 . 1 3}$ & .61 & $\mathbf{3 . 3 3}$ & .60 \\
\hline Allowed to make a lot of & & & & & .52 \\
\hline decisions on my own** & $1-4$ & $\mathbf{3 . 0 6}$ & .61 & $\mathbf{3 . 4 6}$ & .57 \\
\hline Discretionary power* & $1-5$ & $\mathbf{3 . 8 2}$ & .79 & $\mathbf{4 . 0 8}$ & .67 \\
\hline Control over work** & $1-5$ & $\mathbf{4 . 1 6}$ & .70 & $\mathbf{4 . 5 5}$ & .52 \\
\hline & & & & & \\
\hline Clarity of goals & $(.74)$ & & & & .75 \\
\hline Clearly defined goals* & $1-5$ & $\mathbf{3 . 7 6}$ & .87 & $\mathbf{3 . 9 7}$ & \\
\hline Knowing what is expected & $1-5$ & $\mathbf{3 . 9 3}$ & .83 & $\mathbf{4 . 0 6}$ & .87 \\
\hline
\end{tabular}

The items 1, 2, 3, 5, 6 are scaled from 1-4, ranging from "very much disagree" to "very much agree". The items $4,7,8,9,10$ are scaled from 1-5, ranging from "very seldom" to "very often/ always", or from "a very low degree" to "a very high degree". Chi square: * $p<0.05$, ** $p<0.01$.

According to the results (table 3), time pressure in terms of rapid work tempo is the highest ranked aspect among the job demands examined in this study. Both managers and practitioners report being exposed to rapid tempo demands without enough time to fulfill their work tasks properly. Among the four dimensions of autonomy examined in this study, to have "control over work", and "freedom to decide how to perform the work", and "to make decisions on my own" are rated at the highest mean level ("very much agree") by both positions, while the scope of discretion is rated at the highest mean level by managers only. Among the organisational rewards, five out of ten aspects show significant mean differences between the managers and front line workers assessments. The managers report a higher level of autonomy (considering all four items) and goal clarity, compared to the practitioners. Employees in managerial positions also experience more conflicting demands and lack of resources to fulfil their job, being instructed tasks without adequate resources to solve them. Given these differences in perceived opportunities between the two hierarchical positions in 
the social services, how do the various aspects influence on the workers' overall satisfaction?

Table 4. Correlation between overall job satisfaction and various rewards (intrinsic, organisational and social)

\begin{tabular}{|l|r|r|}
\hline $\begin{array}{l}\text { Job aspects/ } \\
\text { rewards }\end{array}$ & $\begin{array}{c}\text { Practitioners } \\
\text { job satisfaction }(\mathrm{n}=349)\end{array}$ & \multicolumn{1}{c|}{$\begin{array}{c}\text { Managers } \\
\text { job satisfaction }(\mathrm{n}=99)\end{array}$} \\
\hline Intrinsic Personal rewards & $.514^{* *}$ & $.432^{* *}$ \\
\hline Accomplishment & $.343^{* *}$ & $.343^{* *}$ \\
\hline Organisational: Job-demands & $-.255^{* *}$ & $-.285^{* *}$ \\
\hline Autonomy & $.271^{* *}$ & .070 \\
\hline Clarity of goals & $.351^{* *}$ & $.395^{* *}$ \\
\hline Social: Co-worker support & $267^{*}$ & $.212^{*}$ \\
\hline Superior support & $.380^{* *}$ & .075 \\
\hline Public approval & $.266^{* *}$ & $.242^{*}$ \\
\hline Client recognition & $.254^{* *}$ & .116 \\
\hline
\end{tabular}

${ }^{*} p<0.05, * * p<0.01$

Table 4 presents the data from the correlation analysis, showing the relationship between overall satisfaction and the three job dimensions for each position. In general, the data show that job satisfaction first of all is associated with intrinsic rewards by both practitioners and managers (.514 and .432). The more positive view the workers have on their own helping abilities and accomplishment, valuing their work as varied, interesting and self-developing, the more satisfied they seem to be.

Considering the organisational dimensions, results show that both practitioners' and managers' overall satisfaction are positively associated with having clarity of goals (.351 and .395) and negatively associated with job demands (-.255 and - .285). However, having autonomy shows no significant influence on managers' satisfaction (.070).

According to the data, social rewards influence the satisfaction of the two positions in different ways. In general, receiving social rewards (support and recognition) seems to be more important sources of the practitioners' satisfaction, compared to the managers. In comparison, receiving public approval and co-workers support are the two only social rewards having any significant influence on managers' satisfaction. While receiving managerial support seems to be the most satisfying social reward among practitioners (.380), the mangers seem less dependent on support from their superiors to feel satisfied (.075). Client recognition seems to be particularly important to the practitioners only, showing no significant correlation in the case of managers.

\section{Discussion}

Despite the time pressure, lack of resources and heavy work loads, results indicate that the practitioners and managers are both overall satisfied with working in the social services. The high level of self-reported satisfaction is in line with similar studies among human service workers in other European countries (MacLean and Andrew 2000, Poulin 1995 ${ }^{10}$ ). The respondents' overall satisfaction can be explained in several ways. First, the reported satisfaction may be due to social desirability that often affects how people respond, when asked this kind of questions. Second, since the expectations towards the employees' present jobs are defined through the work contract, most employees will express a general satisfaction when asked, even if they would wish to have a different kind of job. Other explanations are related to the gender aspects, addressing the overwhelming female majority 
of social workers in the services. According to some theories, female workers are considered to bring different values and priorities than men into the job, resulting in lower expectations to employment and to be more satisfied with less (Spector 1997, McNeely 1992).

Consequently, women may express high job satisfaction levels despite being in positions of lower rank, and despite earning less compared to men. However, this approach is disputed among other theorists, claiming that gender differences in work orientation and satisfaction is caused by the structural differences in the types of jobs available to men and women (Kalleberg 1977).

The workers' strong emphasis on the intrinsic job aspects, including both self realisation and altruistic rewards, indicate a high degree of motivation for human service work in both work positions. This is supported by several other studies which indicate that statutory social worker are highly committed to their work and well motivated by contact with service users, feeling they can make real difference to peoples' life (Mc Lean and Andrew 2000, Huxley et al. 2005, Collins 2008).

According to a comparative study of Norwegian and American social workers, the strongest predictors of job satisfaction were the intrinsic rewards in terms of challenges and self developmental opportunities (special abilities), interesting work tasks, and ability to see the results of ones efforts (Himle, Srinika and Thyness 1986).

Traditionally, social work is associated with a professional practice coupled to the image of idealism and commitment to serve the public interest in particular. Due to the ethics of social work, the workers are expected to be committed, with a strong belief in the credibility and helpfulness of their professional role. Since the altruistic values are part of the workers' professions ethos, the social workers may more or less consciously exaggerate its importance when responding to the survey. Nevertheless, the results indicate that social service work still make helping abilities and self development possible to social service managers and practitioners.

The mean differences between the two groups regarding their emphasis on intrinsic rewards are moderate, probably because managers holding leading positions in social services are guided by the same service ethos and committed to the same professional norms and values as practitioners, often based on the a common vocational training of social work. The findings are interesting regarding the more administrative tasks of managers involving human resource management and budgetary allocations, which demand another type of problem solving abilities compared to the practitioners' client work. Based on the positional differences, the managers are significantly more satisfied with their own problem-solving skills compared to the front line workers. Managers also report more opportunities for acquiring skills and personal development, probably due to their administrative positions and tasks.

As in the other studies reviewed, job satisfaction is first of all associated with intrinsic factors such as individual efforts and challenges, helping people and quality of service personally provided. Job demands such as time pressure and lack of resources are of less importance to the overall satisfaction experienced by practitioners, compared to the intrinsic sources of satisfaction.

As expected, managers and practitioners perceive the organisational job aspects and opportunities differently. Due to their authority and leading positions, managers have a wider scope of decision making. On the other hand, findings show that social service managers, in comparison to practitioners, experience more conflicting demands and more often are given tasks without adequate resources to solve them. Along with the high level of time pressure reported by both groups, job demands may constitute a potential source of stress and dissatisfaction. 
Regarding the relationship between organisational goal clarity and general satisfaction in the workplace, both clarity of goals and definition of work (knowing what is expected) are positively associated with being satisfied within both groups, and more so among the managers ${ }^{11}$. The result may be a reflection of the well known distance between overall goals and practical organisation in the welfare services. Second, the high ratings of conflicting demands reported by managers in the present study indicate that the managers, holding senior and middle level positions, may be more exposed to role ambiguity due to contradictory pressure and incompatible demands, positioned between upper administration and their subordinates ${ }^{12}$. Due to the nature of their work, social workers may face divided loyalties between the organisation and their professional belief system and personal values, and contradictory pressure from client needs opposed to bureaucratic rules and regulations. This is part of their role as street level bureaucrats. A range of studies have shown that role ambiguity is a central issue for people who work in the human services and an important source of dissatisfaction among the workforce (Allen et al. 1990, Balloch et al 1998). Moreover, stress is often related to conflicting expectations and demands. According to a previous study of Norwegian social workers, sampled from twenty-two public welfare offices, experiencing role conflict and ambiguity contributed to both job dissatisfaction and stress (Stjernø 1983).

According to the present study, the Norwegian social work staff including managers, still experience a high autonomous level: they are allowed to make a lot of decisions on their own and to choose how to perform their work. In line with Lipsky's theory, the street-level bureaucrats in the local welfare agencies have wide discretion over the dispensation of benefits and the allocations of public sanctions (Lipsky 1980). The opportunities of making independent choices mostly occur among social workers in (senior and middle level) administrative positions. As local managers they are given increased responsibilities for budgetary expenditures and cost cuttings, expected to be financially accountable. Obviously, managers have the mandate to make decisions and exercise discretion in a wider manner than practitioners.

In general, workers in Norway and many other Nordic countries, seem to enjoy better opportunities for discretion and involvement in decision making, and better work quality than in many other OECD countries (Clark 2005). According to Laws and administrative guidelines the Norwegian statutory social workers are delegated a relatively wide scope of decision making in the social services compared to other public civil servants managed by rules and regulations (Jessen 2007). Although perceived control over work often is considered a motivational characteristic of work, associated with positive health and work related outcomes (Hackman and Oldham 1976, Spector 1997), this study suggest autonomy to be of little impact on the overall job satisfaction. Despite good opportunities to make decisions and use discretionary power, the managers' job satisfaction is less influenced by autonomy, compared to other rewarding aspects reported in this study. Since social service managers often experience strong and conflicting demands, accountable for any decisions made by subordinates, the autonomy assigned to them is not necessarily highly required for them to feel satisfied. The complex work situation and vulnerable position as managers in social services may equally well lead to an ambiguous attitude regarding the consequences of an extensive autonomy.

Regarding the social rewards, findings show that both managers and practitioners experience a relatively high degree of social support from superiors and colleges. In line with literature, being valued in a broader context is considered to be important factors regarding the workers self-esteem. Nevertheless, social support from the management is far more important to the job satisfaction of practitioners. In the work place, social support provided by supervisors and colleagues is generally considered to have important stress-reducing functions (Koeske 
and Koeske 1989, Le Blanc et al 2000). Himle et al (1986) also reported that emotional support from supervisors was interrelated with job satisfactions, lower levels of burnout and work stress. On the other hand, other studies of job satisfaction point to a moderate effect of organisational support (Koeske and Kelly 1995, Acker 1999). To the practitioners examined in this study, support from the social service management is one of the most important sources of job satisfaction, second to intrinsic rewards. Facing complex cases, expectations of work performance and conflicting demands, the need for managerial advice and supervision may be significant to case workers in particular. Although they may receive emotional support through collegial relations and supervision through the team work, the support from managers seems even more important in the sense of recognition and self esteem.

A commonly reported source of stress for social workers is being out of sympathy with the way services are run (Huxley et al 2005). According to this previous study, some of the most unsatisfactory aspects of the social workers job context arise from not being valued by the wider society, while some of the most satisfactory aspects of the social workers job context arise from social support. Consequently we expected that client recognition and public approval would be significant contributing sources to job satisfaction too. This assumption does not appear to be correct, when investigating the satisfaction of managers and subordinate employees separately. In spite of disapproval and lack of acknowledgment reported by the social service staff in general, client recognition seems to be of less importance when it comes to the overall satisfaction of managers. A connection can be made to another research, showing that gratitude from clients and their relatives were not particularly satisfying for either managers or social workers (McLean, 1999). One possible explanation may be that social workers are aware of the conflicting role embedded in statutory social work, and the critiques directed towards the means testing and discretionary services provided. Consequently the practitioners observe their own working role through the depreciating eyes of the public, expecting less recognition and gratitude from their clients. Despite this awareness, recognition is considered to be an important aspect in building a trusting client relationship and for that reason significant to the overall satisfaction of client workers as well.

\section{Conclusion}

Investigating the various sources of satisfaction, the result addresses some contradictions and challenges for social service work. The study suggest that the least satisfying aspects were extrinsic resources over which the workers had little control, such as time available, adequate resources to solve the tasks, and social approval in particular. Although the service providers estimate their own working skills and performance to be of good quality, reporting a sincere interest in social work tasks, they conceive a relatively high degree of external depreciation. On the one hand social professionals have the right intensions and preconditions in building mutual recognition in client-relations; on the other hand they experience little client recognition. Apparently, it seems like the intrinsic rewards somehow compensate for the lack of appreciation they perceive.

The experiences by social workers of not being recognized or valued, most likely reflect the prevailing public view on social assistance and clients negative exposure to the services. Discretionary services, such as social services, have a relative high probability to produce negative judgements among the recipients of social benefits and to raise mistrust or suspicion about discrimination and abuse amongst providers (Kumlin 2002, Rothstein 2001). Social service workers who are instructed to use professional discretion to decide if the claimants should be granted cash benefits are therefore likely to be exposed to dissatisfaction and negative reactions from claimants whose request for help or benefits has been rejected. The disapproval reported, may be due to the stigmatizing of recipients 
of social assistance and the different elements of social exclusion of the service users with whom they work. Because the means-tested social assistance is targeted at the poorest and most vulnerable segments of the population, the social service work is associated with poverty and deprivation.

The assumption that acknowledgement is an important source of satisfaction to social workers, is confirmed by the results of this study. Since social approval is linked to the question of legitimacy, being acknowledged is closely related to the occupational selfperception and professional identity. Despite the formal knowledge basis and the problemsolving purposes of social work, social professionals receive little informal recognition and approval. According to Collins (1990), the knowledge systems serve a symbolic purpose and hence functioning primarily as prestigious ideological bases in order to give occupational status and honor to the professions. In this perspective, lack of acknowledgement may be related to the occupational status of social work that traditionally has been carried out by women, associated with rather low status and wages and limited career opportunities. The result calls for flexible and sensitive responses from the public welfare organisations. One of the challenges is to make jobs in social sector attractive and consistent with the workers' motives and values (Katzell and Thompson, 1990). Moreover, the administration has to ensure better opportunities for self- development at work through professional supervision and educational training of the staff. The negative influence of job demands reported by both managers and practitioners, addresses the question of available resources and manageable workloads necessary to maintain the high level of job satisfaction and to expand the positive engagement and interest for social service work. In order to empower social workers to increase and maximize job satisfaction, it is therefore necessary to acknowledge the workers effort and trained competence. Furthermore, organisations have to ensure a better work environment to buffer the impact of negative attitudes towards the services they provide, and to maintain and strengthen the professional commitment that is required when working in the human services.

The workers emphasize on social support, underline the importance of focusing on the organisational culture in order to understand the various sources and dynamics of support in the workplace. The results also indicate that leadership is a key factor in organizations that will influence employee job satisfaction. In order to empower social workers to increase and maximize job satisfaction, it is necessary for leaders to ensure supporting systems and encourage appropriate coping strategies. Thus, building a socially supportive work environment may forestall social worker turnover and dissatisfaction. According to Cherniss (1980), support from supervisors and colleagues may lessen some of the emotional tension among workers and help them gain a more realistic perspective of client problems, providing technical information and practical instruction for client work. Social support, provided by co-workers along with regular supervision, is likely to buffer against negative effects of stress and burnout and to provide coping strategies for coping with emotional demands (Koeske and Koeske 1984, Collins 2008). Consequently, the social work organisations need to care for, value and recognize workers by paying sufficient attention to their contra dictionary work roles and emotional demands. Further, supervision needs to focus on nurturing emotional support in helping social workers feel appreciated and significant to the organisation in spite of public disapproval, supporting them to cope with stress and negative attitudes. The result points to the challenges and responsibility of the welfare administration to create an organizational climate that recognize and sustain the worth and contribution of the social professionals. 
${ }^{1}$ According to Herzberg's (1959) well known theory of motivation, several job characteristics (or factors) are identified as motivators, contributing to job satisfaction.

2 Since 2006, the National Social Security Directorate, is being merged with the National Employment Directorate, and named the New Labour and Social Security Directorate (NAV). NAV is run and financed by the national government, making social insurance a state responsibility, while the social services are financed and administered by the local councils.

${ }^{3}$ The ideal of human service and social work consist of a commitment on the part of professionals not to abuse their knowledge and skills, to serve and not to exploit their clients, and to work for the greater community good (Goode 1969).

4 According to Jensen 2003 , both self directed and altruistic motives were given primacy to the vocational choice of the Norwegian social work students).

${ }^{5}$ According to the "demand-control model" of Kasarek (1979), control over work reduces the negative effects of high workloads and other job demands. When expanding this demand-control model by including the dimension of social support, Johnson (1986) proved that the less favorable job situation was one of high demands combined with a lack of control (freedom to decide) and a lack of social support.

${ }^{6}$ According to Elpers and Westuis (2008) management usually deals with bureaucratic activities, whereas leadership deals the interpersonal relations ships in organizations. In the social services these roles often are interchangeable, whereas leaders are placed in both a leadership and management roles.

7 The present study do not comprise all relevant items /variables. The issues of commitment, stress, re-organisations, and work loads are leaved out.

8 In empirical research, autonomy has traditionally been operationalised through variables that measure the employees' opportunities to be independent (Svalund 2003), concerning the workers ability and opportunity to determine what tasks to do, how to do the work, and what the aim of the work should be.

${ }^{9}$ The survey, measuring several aspects of working condition among 4500 civil servants employed by the Norwegian government, show that 82 percent of the servants report being equally "very" or "moderately" satisfied. Presented in the journal "Stat og Styring" 2007 (In english; "State and Governmental Steering"),

10 Poulin's study of job satisfaction among social work administrators and supervisors, show the same satisfactory mean scores of 4 on a five point scale for managers.

12 According to Balloch et al (1998) role ambiguity occurs when there is uncertainty about the scope of job and about the expectations of others.

\section{References}

Abu-Bader, S.H. (2000): "Work satisfaction, burnout \& turnover among social workers in Israel: a causal diagram; Journal of International Social Welfare, vol.9, (3), 191-200

Acker, G. M. (1999): The impact of clients' mental illness on social workers' job satisfaction and burnout. Health and Social Work, 24 (2),112-119

Allen, N.J., \& Meyer, J.P.(1990): The measurement and antecedents of affective, continuance and normative commitment to the organisation. Journal of Occupational Psychology, vol. 63, 1-18

Arches, J. (1991). "Social structure, burnout, and job satisfaction", Social Work, vol.36 (3), 202-206

Balloch, S., Pahl, I. \& McLean, J. (1998) "Working in the social services: Job-satisfaction, stress and violence", British Journal of Social Work, vol. 34 (6), 871-895.

Blood, M.R.(1969) Work Values and job satisfaction. Journal of Applied Psychology, vol. 53, 456-459 
Bussing, A. (1999) A dynamic model of work satisfaction: qualitative approaches. Human relation. Vol. 52, 999-1028

Carver, C., Scheier, M. and Weintraub, J. (1989) "Assessing coping strategies: A theoretically based approach", Journal of Personality and Social Psychology, vol. 56, 267- 83

Cherniss, C. (1980): Professional burnout in human service organizations. New York: Praeger.

Clark, C. (2005): The Deprofessionalisation Thesis, Accountability and professional character, Social Work \& Society, Volume 3 (2): 2005

Collins, R (1990): Changing conceptions in the sociology of the professions, in Torstendal, $\mathrm{R}$ og M. Burrage (Ed), The Formations of Professions. Knowledge, State and Strategy. Sage Publication. London

Collins, S. (2008): Statutory social workers; stress, job satisfaction, coping, social support and Individual differences. British Journal of Social Work. Vol 38 (6), 1173-1193

Elspers, $\mathrm{K}$ and Westhuis, D.J. (2008): Organisational leadership and its impact on social workers' job satisfaction: A national study, Administration in Social work..Vol. 32

Evetts, J (2006): Trust and professionalism:Challenges and occupational changes, Current Sociology Vol.54 (4), 515-513). Sage Publications.

Foster, J. J. (2000) Motivation in the workplace, in Chmiel, N. (Ed), Introduction to work and organisational psychology: a European perspective (pp.302-326) Oxford Blackwell Publisher INC.

Freund,A. (2005): Commitment and Job satisfaction as Predictors of Turnover Intentions Among Welfare Workers. Administration in Social Work, Vol. 29 (2) 2005

Gibbs, J. (2001): Maintaining the front line workers in child protection: A case for refocusing supervision. Child Abuse Review, Vol.10, 323-35.

Gibson, F., McGrath, A., NS Reid, N. (1989): "Occupational stress in social work", British Journal of Social work, vol. 19 (1), 1-18

Hackman, J.R. and Oldham, G.R. (1976): Development of the Job Diagnostic Survey. Journal of Applied Psychology, Vol. 55, 259-285.

Halvorsen,K. (2005): Grunnbok i Helse og Sosialpolitikk. Universitetsforlaget.3 utgave. Oslo. Harris, J og McDonald, C.(2000): Post-Fordism, the welfare state and the personal social services: A comparison of Australia and Britain, British Journal of Social Work Vol.30, 51-70.

Healy, K. and Meagher. G. (2004): "The Reprofessionalization of Social Work: Collaborative Approaches for Achieving Professional Recognition". British Journal of Social Work .Vol. 34, 243-260.

Herzberg, F. (1959): The Motivation to Work, John Wiley, New York

Himle, D. Srinika, J., \& Thyness, P. (1986): Predictors of job satisfaction, burnout and turnover among social workers in Norway and the USA: a cross-cultural study. International Social Work. Vol.29, 323-34 
Himle, D., Jayaratne, S., Thyness, P. (1989): The effects of emotional support on burnout, work stress and mental health among Norwegian and American social workers. Journal of Social Service Research, Vol. 13 (1), 27-45.

Huxley, P. et al (2005): Stress and Pressures in Mental Health Social Work: the Worker Speaks. British Journal of Social Work. Vol. 35, (7), 1063-1079.

Jessen, J.T., (2007): "Mindre frihet og skjønn i forvaltning av velferd?" Tidsskrift for Velferdsforskning, Vol. 10(4), 246-261.

Jones, F., Fletcher, B. and Ibbetson, K. (1991): "Stressors and strains among social workers: Demands, supports, constraints and psychological health. British Journal of Social Work, vol. 21 (5), 443-69

Jones, C. (2001): "Voices from the front line: State social workers and New Labour. British Journal of Social Work, 31 (4), 547-63

Kalleberg, A.L.(1977): Work, Values and Job Rewards: A Theory of Job satisfaction. American Sociological Review, vol.42 (1), 124-143

Kasarek, R. A. (1979): Job demands, job decision latitude, and mental strain: Implications for job redesign. Administrative Science Quarterly, 24: 285-308

Kasarek,R.A. \& Theorell, T. (1990): Healthy Work. New York: Basic Books.

Katzell, R.A. \& Thompson, D.E. (1990): Work motivation: Theory and practice. American Psychologist, 45, 144- 153

Koeske, G., Kirk, S., Koeske, R. \& Rauktis, M.B. (1994): "Measuring the Monday blues: validation of a job satisfaction scale for the human services", Social Work Research, vol.18, no 1. pp. 27- 35

Koeske,G.F. \& Koeske, R.D. (1989): Workload and burnout: Can social support and perceived accomplishment help? Social Work, 243-248

Koeske,G.F. \& Kelly,T. (1995): The impact of over involvement on burnout and job satisfaction. American Journal of Orthopsychiatri, vol 65, 282-292

Kumlin, S. (2002): The Personal \& The Political. How Personal Welfare State Experiences affectPolitical trust and Ideology. Department of political science. Gøteborg University.

Le Blanc, P. de Jonge, J. and Schaufeli, W. (2000): Job stress and health. In N. Chmiel (ed). Introduction to work and organisational psychology, A European perspective. Oxford: Blacwell Publisher. Ltd.

Le Grande, J. (2003): Motivation, Agency, and Public Policy of Knights \& Knaves, Pawns \& Queens. Oxford University Press.

Lipsky, L. (1980): Street Level Bureaucracy: Dilemmas of the Individual in Public Services, Russell Sage Foundation, USA.

Lødemel, I.(2001): "National objectives and local implementation of workfare in Norway" in 
Lødemel,I \& H. Trickey: An offer you can't refuse. Workfare in international pespective. The Policy Press.

March and Triseliotis, J. (1996): Ready to Practice: Social Workers and Probation Officers: Their Training and First Year in Work, Avebury, Aldershot.

Mc Lean, J. (1999): "Satisfaction, Stress and Control over Work", in Social Services: Working under Pressure, eds. S. Balloch, J. McLean \& M. Fisher, The Policy Press, Bristol.

McLean, J and Andrew, T. (2000): Commitment, satisfaction, stress and control among social services managers and Social Workers in the UK. Administration in social work vol 23, 93-117

McNeely, R.L. (1992): ““Job Satisfaction in the Public Social Services: perspectives on Structure, Situational Factors, Gender, and Ethnicity", in Human Services as Complex Organisations, ed.Y. Hasenfeld, Sage, London.

Papadaki, V. and E. Papadaki (2006): Job satisfaction in Social Services in Crete, Greece: social workers'views. European Journal of Social Work. Vol.9 (4), 479-495

Penna,S., Paylor,I. \& Soothill,K. (1995): Job satisfaction and Dissatisfaction: A study of Residential Care Work, National Institute for Social Work, London.

Poulin, J. (1995): " Job satisfaction of social work supervisors and administrators" Administration in Social Work, vol.19 (.4), 35-49.

Regehr et al (2004) "Predictors of post traumatic distress in child welfare workers: A linear structural equation model". Children and Youth Services Review, Vol. 26 (4),331-46

Rothstein, B., 2001. The Universal Welfare State as a Social Dilemma. Rationality and Society. 14, 190-214

Solheim, L.J and Øvrelid, Ø. ,2001. Samhandling $i$ velferdsyrke. Fagbokforlaget. Bergen

Stjernø,S. (1985): Sosialkontor-undersøke/sen: Sluttrapport. NKSH rapport nr. 85:2

Stjernø, S. (1983): Stress og Utbrenthet. Universitetsforlaget, Oslo

Svalund, J. (2003): Organisering, autonomi og arbeidstempo", Søkelys på Arbeidsmarkedet, 20: 87-94.

Spector, P. (1997): Job Satisfaction, Sage, London.

Stalker, C.A., Mandell, D. \& K.Frensch (2007): Child welfare workers who are exhausted yet satisfied with their jobs: how do they do it? Child and Family Social Work. Vol. 12, 182-191

Thompson, N., Murphy, M \& Stradling, S. (1994): Dealing with Stress, Basingstoke: Macmillan.

General Nordic Questioner (2001): Generelt spørreskjema for psykologiske og sosial faktorer i arbeid. Brukerveiledning og vedlegg 2 til QPS Nordic, in STAMI -rapport årg.2, Vol.1. Oslo

Weiss-Gal, I. \& P. Welbourne (2008): "The professionalisation of social work: a crossnational exploration", in International Journal of Social Welfare, Vol.17, no 4, pp. 281-290. 